\title{
Chromatographic Determination of Imidazole Compounds in the Whale Meat
}

\author{
Michizo Suyama, Takeshi Suzukr, and Junsaku Nonaka* \\ (Received Jan. 5, 1967)
}

The two imidazole compounds, carnosine ( $\beta$-alanylhistidine) and anserine ( $\beta$-alanyl1-methylhistidine), have been reported to occur widely in the muscle of various kinds of animal ${ }^{1,2)}$. Besides these $\beta$-alanyldipeptides, the presence of a new dipeptide balenine ( $\beta$-alanyl-3-methylhistidine) has been recently demonstrated in the extractives of the muscle of whale ${ }^{3-5)}$. The chromatographic analyses on carnosine and anserine, together with the basic amino acids, were made by several workers ${ }^{6-10)}$. The separation of balenine and 3-methylhistidine from these constituents, however, has not yet been carried out except by POCchiari et al. ${ }^{3}$

The present investigation was undertaken to find out a separation method using ion exchange column chromatography for these dipeptides and related imidazole compounds, and to determine their concentrations in the extractives of whale meat. The details are given below.

\section{Experimental}

Materials. L-Histidine and L-carnosine purchased from Nutritional Biochemicals Corporation, L-anserine nitrate from Cyclo Chemical Corporation, L-1-methylhistidine from California Corporation for Biochemical Research, L-3-methylhistidine from Mann Research Laboratories, were used. Balenine was obtained from the extractives of fin whale meat by the procedures of HORISAKA and MUSASHI ${ }^{11}$ and of NAKAI and TsUJIGADO ${ }^{12)}$. The paper chromatographic separation using a solvent system ${ }^{13)}$ of phenol and hydrochloric acid was also used. The purity of these compounds was examined by the ion exchange column chromatographic method of SPACKMAN et al. ${ }^{7}$ and by nitrogen determination, respectively.

Preparation of the extractives of whale meat. Fresh whale meat, obtained from the dorsal portions of duplicate specimens and stored in the frozen state, was used. The meat was extracted with $1 \%$ picric acid in a blender as described by HamiLToN and $\mathrm{TARR}^{14}$. The extractives were filtered and freed from picric acid by means of a column of Dowex $2-\times 8$ in chloride form accorling to the procedure of STEIN and MOORE ${ }^{15)}$. The effluent was evaporated to small volume in a rotary evaporator, diluted quantitatively, and kept in the frozen state until used.

* Tokyo University of Fisheries, Konan, Minato-ku, Tokyo, Japan (須山三干三・鈴木 健 - 野中 順三九, 東京水産大学).

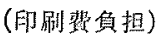


Analytical methods. Chromatographic analyses were, for the most part, performed with an amino acid analyzer (Hitachi KLA-2) according to the technique of SPACKMAN et al. ${ }^{7)}$ using a $0.9 \times 50-\mathrm{cm}$ column of Amberlite IR-120. In order to see the availability of the procedure of POCCHIARI et al. ${ }^{3)}$, a $0.9 \times 150-\mathrm{cm}$ column of Amberlite IR-120 was used at $50^{\circ} \mathrm{C}$. For DAVEY's method ${ }^{6\rangle}$, a $0.9 \times 55-\mathrm{cm}$ column of Dowex $50-\times 4$ and $0.2 \mathrm{M}$ borate buffer solution of $\mathrm{pH} 8.00$ were prepared, and amino acid concentrations in 1-ml fractions obtained at the rate of $5 \mathrm{ml}$ per hour by the collector were determined by the photometric ninhydrin method ${ }^{16}$.

\section{Results and Discussion}

Separation of carnosine, anserine and balenine by the procedure of $D_{\text {AvEY. An }}$ aliquot of each solution of these $\beta$-alanyldipeptides was chromatographed by the procedure of DAVEY ${ }^{6}$. The results are summerized in Fig. 1 and indicate that the elution peaks for carnosine, anserine and balenine are at 59-, 66- and 68-ml effuents, respectively. When a mixture of these peptides was chromatographed, two peaks are obtained as shown in Fig. 2. It is evident from these figures that anserine emerges together with balenine just behind carnosine from a $55-\mathrm{cm}$ column, and the method

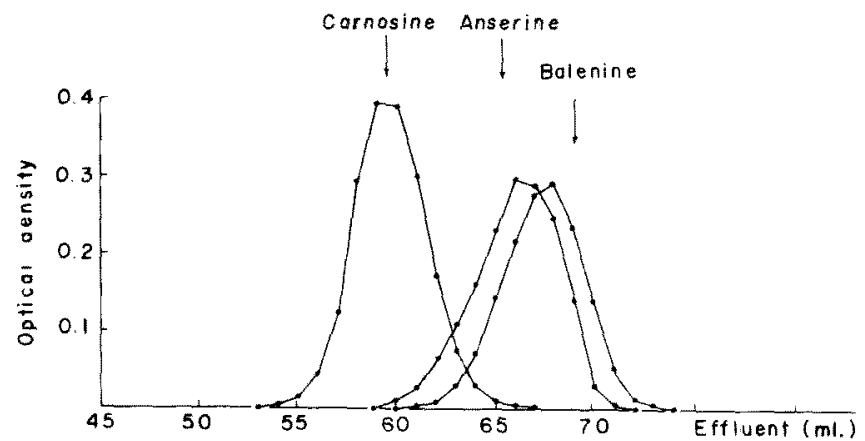

Fig. 1. Elution peaks of carnosine, anserine and balenine from a $55-\mathrm{cm}$ column of Dowex $50-\times 4$.

Conditions: $0.2 \mathrm{M}$ borate buffer, $\mathrm{pH} 8.00$ and $0.181 \mathrm{~N} \mathrm{Na}$ ions, at $25^{\circ} \mathrm{C}$.

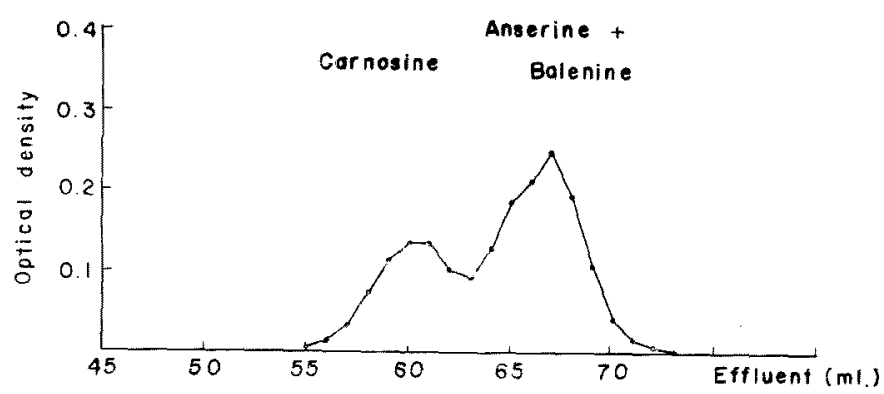

Fig. 2. Chromatographic analysis of a mixture of carnosine, anserine and balenine from a $55-\mathrm{cm}$ column of Dowex $50 \cdot \times 4$.

Conditions: Same as those in Fig. 1. 
seems not applicable for the determination of these dipeptides.

$D_{A V E Y}^{6,17)}$ reported the presence of relatively large amounts of carnosine and anserine in the muscle tissues of blue and fin whales using his procedure, and LukToN and OLCOTT ${ }^{18)}$ recognized a similar trend in a humpback whale by DAVEY's method with the exception that the column length was extended from $50 \mathrm{~cm}$ to $65 \mathrm{~cm}$. The amount of anserine in the muscle of these whales, however, should be re-examined, since a large amount of balenine is found in Mystacoceti as shown in Table 1.

Examination on the procedure of Pocchrarr et al. The position of the elution peaks of basic amino acids, carnosine and related compounds was determined applying each specimen alone or in combination to the column according to the technique of POCCHIARI et al. $^{3)}$ When the mixture was developed, the peaks for balenine and carnosine were at about 990 and $1035 \mathrm{ml}$ effluents corresponding to 33 and 34.5 hours after the start, respectively. The resolution time thus extended 1.3 folds as compared to that of POCCHIARI et al. though the reason was not obvious.

From a $150-\mathrm{cm}$ column, anserine and 1-methylhistidine were eluted in overlapping 3 -methylhistidine and ammonia, respectively. It has already been shown that anserine is eluted as a zone following but partially overlapping 3-methylhistidine from a $50-\mathrm{cm}$ column of SPACKMAN et al.7) These results, therefore, suggest that the accurate determination of these imidazole compounds may be not attained by these two methods.

Effect of $\mathrm{pH}$ on resolution of imidazole compounds using a $50-\mathrm{cm}$ column of Srackman et al. To improve the resolution, the imidazole compounds were eluted by using $0.38 \mathrm{~N}$ sodium citrate buffer solutions differing in $\mathrm{pH}$ values, from 3.96 to 4.26 , at the rate of $30 \mathrm{ml}$ per hour at $30^{\circ} \mathrm{C}$, as described previously for a $50-\mathrm{cm}$ column by SPACKMAN et al. ${ }^{7)}$ The results are shown in Fig. 3.

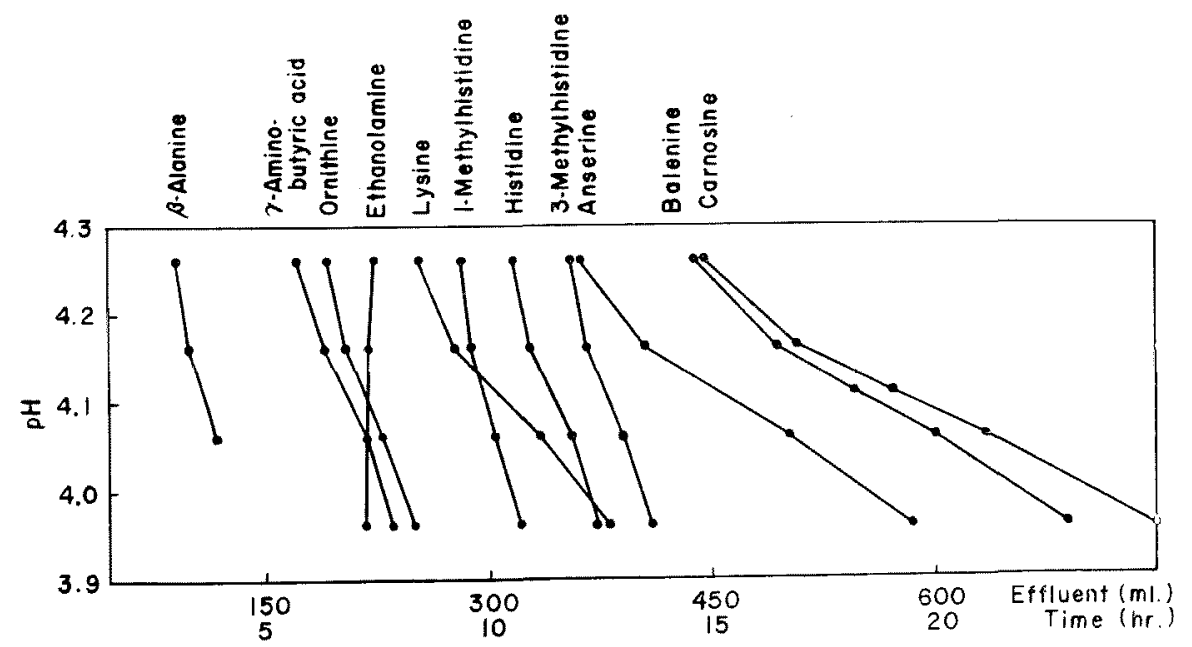

Fig. 3. Effect of $\mathrm{pH}$ on resolution of basic amino acids from a $50-\mathrm{cm}$ column of Amberlite IR-120.

Conditions: $0.38 \mathrm{~N}$ sodium citrate buffer, at $30^{\circ} \mathrm{C}$. 
Table 1. Concentration of imidazole compounds in the extractives of the whale muscle.

\begin{tabular}{|c|c|c|c|c|c|c|c|c|}
\hline & $\begin{array}{c}\text { Total } \\
\mathrm{N}\end{array}$ & Carnosine & Anserine & Balenine & Histidine & $\begin{array}{l}\text { 1-Methyl- } \\
\text { histidine }\end{array}$ & $\begin{array}{l}\text { 3-Methyl- } \\
\text { histidine }\end{array}$ & $\begin{array}{l}\text { Imidazole-N } \\
\text { per total N } \\
(\%)\end{array}$ \\
\hline Mystacoceti & & & 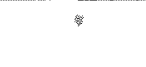 & & & & & \\
\hline \multirow{2}{*}{ Fin whale } & 637 & 140 & 5.0 & 1500 & 2.2 & 0 & 2.8 & 60.8 \\
\hline & 624 & 103 & 4.4 & 1510 & 1.0 & 0 & 3.0 & 60.8 \\
\hline \multirow[t]{2}{*}{ Sei whale } & 715 & 131 & 6.4 & 1840 & 0.5 & 0 & 2.6 & 64.9 \\
\hline & 709 & 138 & 7.5 & 1830 & 1.8 & 0 & 7.9 & 65.5 \\
\hline Little piked whale & 780 & 154 & 22.7 & 1930 & 4.4 & 0 & 6.6 & 63.6 \\
\hline$\left(^{*}\right)$ & 718 & 117 & 49.3 & 1700 & 3.1 & 0 & 9.5 & 61.1 \\
\hline \multicolumn{9}{|l|}{ Odontoceti } \\
\hline \multirow[t]{2}{*}{ Sperm whale } & 440 & 196 & 126 & 3.2 & 2.7 & 0 & 0.9 & 18.1 \\
\hline & 466 & 206 & 83.6 & 1.8 & 2.8 & 0 & 0.5 & 16.3 \\
\hline \multirow[t]{2}{*}{ Pilot whale } & 533 & 227 & 39.0 & 515 & 2.0 & 0 & 9.2 & 35.3 \\
\hline & 549 & 275 & 37.5 & 590 & 3.3 & 0 & 4.6 & 39.3 \\
\hline
\end{tabular}

(*) An infant specimen. 
Concerning the amino acids emerging after lysine, it is apparent that the eluting

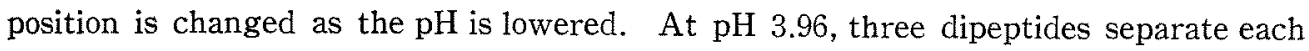
other satisfactorily but histidine emerges on lysine. In addition, the peaks are broad and the time consuming for separation is inconvenient for daily run. At $\mathrm{pH} 4.06$, although histidine is eluted as a zone following but partially overlapping lysine, the resolution is adequate and the time necessary for the exit of carnosine is 22 hours after the start.

Figure 4 shows the effect of concentrations on resolution of balenine and carnosine, namely, as the concentration increases, the peaks become wider and give the steep acclivity at the beginning of the emergence. When the mixture of a small amount of balenine and a large amount of carnosine is chromatographed, the peak of the latter hanging over that of the former is obtained.

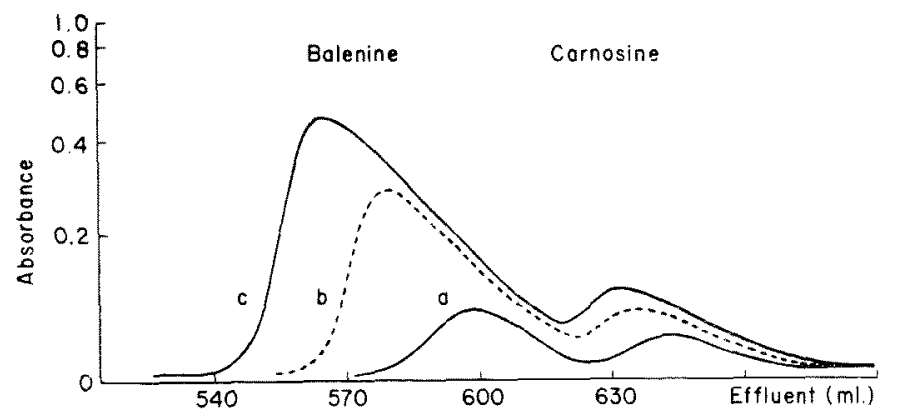

Fig. 4. Effect of concentration on resolution of carnosine and balenine. a: synthetic mixture; $b$ and $c$ : extractives of whale meat. Conditions: $0.38 \mathrm{~N}$ sodium citrate buffer, $\mathrm{pH} 4.06$, at $30^{\circ} \mathrm{C}$.

Determination of imidazole compounds in the extractives of whale meat. The imidazole compounds in the extractives of whale meat were chromatographed with $0.38 \mathrm{~N}$ sodium citrate buffer solution of $\mathrm{pH} 4.06$ using a $50 . \mathrm{cm}$ column of Amberlite IR- 120 at $30^{\circ} \mathrm{C}$. For the determination of histidine, a buffer solution of $\mathrm{pH} 4.26$ was used. The identification of $\beta$-alanyldipeptides was made by chromatographic analysis of the fractions which were hydrolyzed with $6 \mathrm{~N} \mathrm{HCl}$ solution. The results are given in Table 1.

The significant feature of the results is the variation in the concentration of carnosine, anserine and balenine. Among the whales examined so far, the fin, sei and little piked whales, which belong to Mystacoceti, contain a large amount of balenine, an intermediate amount of carnosine, and a relatively small amount of anserine in their muscle. The sperm and pilot whales, which belong to Odontoceti, on the other hand, contain an intermediate amount of carnosine and anserine, differing from the members of Mystacoceti. The sperm whale holds only a small amount of balenine, but pilot whale a relatively large amount of it. In general, the contents of carnosine and anserine are not so high as they are reputed to be so by DAVEY ${ }^{6,17)}$ and LUKTON and OLCOTT ${ }^{18)}$. 
Among histidine and its methyl compounds, histidine and 3-methylhistidine are detected, but their levels are less than $10 \mathrm{mg} \%$. 1-Methylhistidine is not found. In samples of fin, sei and little piked whales, the imidazole compounds account for over $60 \%$ of the extractive nitrogen, and more than $99 \%$ of imidazole nitrogen are occupied by the dipeptides. In sperm and pilot whales, however, imidazole compounds account for only $16-18$ and $35-39 \%$ of the extractive nitrogen, respectively.

The authors express here their sincere thanks to Taiyo Fisheries Co., Ltd. and Nihon Kinkai Hogei Co., Ltd. for supplying the fresh muscle of whales.

\section{References}

1) W. A. WolfF and D. W. Wilson: J. Biol. Chem., 95, 495 504 (1932); 109, 565 571 (1935),

2) J. A. ZAPP and D. W. WILSON: ibid., 126, 9 18, 19 27 (1938).

3) F. Pocchiari, L. Tentori, and G. Vivaldi: Sei. Repts. Ist. Super. Sanità, 2, 188 194 (1962).

4) T. NAKai, N. TSUJigado, and S. AkIYA: J. Biochem., 54, 541 549 (1963).

5) P. O. Dennis and P. A. Lorkin: J. Chem. Soc., 1965, 4968 4772.

6) C. L. DAVEY: Nature, 179, 209 210 (1957).

7) D. H. Spackman, W. H. Stein, and S. Moore: Anal. Chem., 30, 1190 1206 (1958).

8) P. B. HamiltoN: ibid., 35, 2055 2064 (1963).

9) C. H. KirkPatrick and R. A. Anderson: J. Chromatog., 14, 295 297 (1964).

10) J. V. Benson, Jr, and J. A. Patterson: Anal. Biochem., 13, 265 280 (1965).

11) K. HorisakA and A. Musashi: J. Biochem., 53, 271 274 (1963).

12) T. NAKAI and N. TsuJIGado: ibid., 57, 812 814 (1965).

13) T. Wood and A. E. BENDER: Biochem. J., 67, 366 373 (1957).

14) P. B. Hamilton and R. R. TARR: J. Biol. Chem., 158, 375 395 (1945).

15) W.H. SteIN and S. Moore: ibid., 211, 915 926 (1954).

16) E. W. Yemm and E. C. Cocking: Analyst, 80, 209 213 (1955).

17) C. L. DAveY: Arch. Biochem. Bioph̆ys., 89, 303 308 (1960).

18) A. LukToN and H.S. OlcotT: Food Res., 23, $611 \sim 618$ (1958). 